\title{
Kemampuan jamur pelapuk kayu isolat JPA dan Trichoderma Sp. S2-2 dalam mendegradasi tandan kosong kelapa sawit untuk menghasilkan selulosa
}

The capability of wood rot fungus JPA isolate and Trichoderma sp. S2-2 in degradation of oil palm empty fruit bunches to produce cellulose

\author{
ALHIDAYATULLAH ${ }^{*}$, Lisdar I. SUDIRMAN1 \& Okky Setyawati DHARMAPUTRA \\ Departemen Biologi, Fakultas MIPA, IPB. Jl. Meranti, Kampus Darmaga, Bogor 16680, Indonesia
}

Diterima tanggal 12 September 2014/disetujui tanggal 26 Nopember 2014

\begin{abstract}
Oil palm empty fruit bunches $(O P E F B)$ are the lignocellulosic wastes from palm oil processing. They can be used to produce raw materials for value-added products. The purpose of this study was to determine the degradation capacity of JPA wood rot fungi and Trichoderma sp. S2-2 on OPEFB. The $500 \mathrm{~g}$ of substrates consisted of $81 \%$ of OPEFB, $15 \%$ bran, $1.5 \%$ lime and $1.5 \%$ gypsum were used for growing. The substrates were inoculated with five treatments i.e without isolate $(K)$; with JPA isolate (JPA); with Trichoderma sp. S2-2 (T); with the two isolates (JPA + T); and with JPA isolate and after four weeks of incubation inoculated with Trichoderma sp. S2-2 $\quad[(J P A)+T]$. All treatments were incubated for eight weeks. The results showed that JPA+T was the best treatment which the two isolates must be inoculated simultaneously for degradation of OPEFB. Lignin and cellulose content on JPA+T treatment respectively were $20.83 \%$ and $33.77 \%$. C/N ratio of OPEFB degraded with $J P A+T$ was lower than the $C / N$ ratio of TKKS degraded with Trichoderma harzianum and TKKS degraded with EM4 in previous study.
\end{abstract}

[Keywords: Oil Palm Empty Fruit Bunches, degradation, wood rot fungi, JPA Isolate, Trichoderma sp. $S 2-2]$

\section{Abstrak}

Tandan kosong kelapa sawit (TKKS) merupakan limbah lignoselulosa dari pengolahan minyak kelapa sawit. TKKS dapat dimanfaatkan untuk memperoleh bahan baku untuk produk bernilai tambah. Tujuan penelitian ini adalah untuk mengetahui kemampuan degradasi jamur pelapuk kayu isolat JPA dan Trichoderma sp. S2-2 pada TKKS. Sebanyak $500 \mathrm{~g}$ substrat terdiri dari $81 \%$ TKKS, $15 \%$ dedak, $1,5 \%$ kapur, dan 1,5\% gypsum digunakan untuk pertumbuhan. Substrat diinokulasi dengan lima perlakuan yaitu tanpa isolat (K); dengan isolat JPA (JPA); dengan Trichoderma sp. S2-2 (T); dengan isolat JPA dan setelah empat minggu inkubasi, diinokulasi dengan Trichoderma sp. S2-2 [(JPA+T)]. Semua perlakuan diinkubasi selama delapan minggu. Hasil percobaan menunjukkan bahwa perlakuan JPA+T adalah perlakuan terbaik yaitu kedua isolat tesebut harus diinokulasi secara bersamaan untuk mendegradasi TKKS. Kandungan lignin dan selulosa TKKS dengan perlakuan JPA+T masing-masing adalah 20,83\% dan $33,77 \%$. Rasio C/N TKKS hasil degradasi dengan $\mathrm{JPA}+\mathrm{T}$ lebih rendah daripada rasio $\mathrm{C} / \mathrm{N}$ pada TKKS yang didegradasi dengan Trichoderma harzianum dan TKKS yang didegradasi dengan EM4 pada penelitian sebelumnya.

[Kata kunci: Tandan kosong kelapa sawit, degradasi, jamur pelapuk kayu, isolat JPA, Trichoderma sp. S22]

\section{Pendahuluan}

Indonesia merupakan negara penghasil utama minyak kelapa sawit di dunia dengan produksi sebesar 20 juta ton CPO (crude palm Oil) dengan pertumbuhan rata- rata $10-12 \%$. Pada tahun 2010 produksi CPO meningkat antara 5-6\%, sedangkan untuk periode 2010-2020, pertumbuhan produksi diperkirakan berkisar antara 2-4\% (Isroi et al., 2008). Setiap pengolahan 1 ton TBS (Tandan Buah Segar) akan dihasilkan tandan kosong kelapa sawit (TKKS) sebanyak 22-23\% atau sebanyak $220-230 \mathrm{~kg}$ TKKS. Di seluruh Indonesia pada tahun 2004, jumlah limbah TKKS diperkirakan mencapai 18,2 juta ton (Isroi, 2008). Limbah ini belum dimanfaatkan secara baik oleh sebagian besar pabrik kelapa sawit di Indonesia (Pratiwi et al., 2013).

Karakteristik TKKS adalah mempunyai ukuran besar, didominasi oleh bahan-bahan yang sulit melapuk. Salah satu strategi pengolahan limbah sawit adalah mengolah limbah menjadi produk lain yang bernilai tambah. Selulosa merupakan bagian yang dapat digunakan untuk menghasilkan berbagai jenis produk seperti bioetanol, pakan ternak, dan membran selulosa (Lindu et al., 2008). Namun demikian, terdapat ikatan yang erat antara lignin dan selulosa sehingga untuk memperoleh selulosa, maka lignin harus dihilangkan atau didegradasi terlebih dahulu (Anindyawati, 2010).

Jamur pelapuk kayu merupakan jamur yang dapat mendegradasi kayu dengan bantuan enzim lignolitik yang terdiri dari lignin peroksidase (LiP), mangan peroksidase (MnPs) dan fenol oskidase yang disebut lakase (Fitria, 2008). Jamur pelapuk kayu dapat digunakan dalam bioteknologi seperti pada proses biopulping dan biobleaching (Istek et al., 2005). Proses degradasi lignin oleh jamur pelapuk kayu juga berguna untuk bioremediasi polutan (Muslimah \& Kuswytasari, 2013). 
Trichoderma merupakan cendawan yang memiliki aktivitas selulolitik cukup tinggi karena berperan dalam menghidrolisis bahan selulosa melalui aktivitas enzim selulase yang terdiri dari endo-ß3-1,4glukanase dan ekso-ß-1,4-glukanase, dan ß-glukosidase (Martins et al., 2008). Penelitian ini bertujuan untuk mengetahui efektivitas degradasi TKKS oleh jamur pelapuk kayu isolat JPA dan Trichoderma sp. S2-2. Hasil degradasi ini diharapkan mampu menghasilkan selulosa sebagai bahan baku produk bernilai tambah.

\section{Bahan dan Metode}

Penelitian dilakukan dari bulan Januari 2012 sampai dengan bulan Septermber 2012 di Kampus Darmaga, Institut Pertanian Bogor (IPB). Pengukuran kandungan C-organik dan N-total dilaksanakan di Laboratorium Departemen Ilmu Tanah dan Sumber Daya Lahan, IPB sedangkan penentuan kandungan lignin dan selulosa dilaksanakan di Laboratorium Ilmu dan Teknologi Pakan, Departemen Ilmu Nutrisi dan Teknologi Pakan, Fakultas Peternakan IPB. Bahan yang digunakan adalah tandan kosong kelapa sawit (TKKS) yang diperoleh dari PT. Perkebunan Nusantara VIII, karboksimetil selulosa (CMC), asam tanat $1 \%$, jamur pelapuk kayu isolat JPA, dan Trichoderma sp. S2-2. yang diisolasi dari PT. Perkebunan nusantara IV (PTPN IV).

\section{Kultur isolat JPA dan Trichoderma sp. S2-2}

Semua isolat disimpan dalam bentuk biakan pada media agar-agar miring sukrosa kentang (ASK) dengan komposisi terdiri dari : $1 \mathrm{~L}$ aquades, $200 \mathrm{~g}$ kentang, $20 \mathrm{~g}$ gula pasir, $500 \mathrm{mg}$ antibiotik kloramfenikol, dan $20 \mathrm{~g}$ agar-agar. Media tersebut juga digunakan sebagai media untuk meremajakan atau perbanyakan biakan murni di media agar-agar cawan.

\section{Uji lignolitik dan selulolitik kedua isolat}

Uji lignolitik menggunakan media agar-agar cawan yang terdiri atas $20 \mathrm{~g} / \mathrm{L}$ agar-agar yang dicampur dengan $1 \%$ asam tanat, sedangkan uji selulolitik menggunakan media agar cawan yang terdiri atas $20 \mathrm{~g} / \mathrm{L}$ agar-agar yang dicampur dengan $1 \%$ CMC. Kedua isolat tersebut masing-masing diinokulasikan pada kedua media agar-agar cawan dan diinkubasi selama 10 hari. Pengamatan aktivitas lignolitik dilakukan dengan melihat keberadaan zona berwarna coklat pada media, sedangkan aktivitas selulolitik dilihat dari kemampuan kedua isolat tumbuh pada media.

Pembuatan bibit jamur pelapuk kayu isolat JPA dan Trichoderma sp. S2-2

Media bibit induk dibuat dari $1 \mathrm{~kg}$ biji jagung yang telah direbus dengan $400 \mathrm{~mL}$ aquades sampai merekah dan dimasukkan ke dalam botol (volume $250 \mathrm{~mL}$ ) sebanyak $185 \mathrm{~g}$. Selanjutnya, media jagung tersebut disterilkan di dalam autoklaf pada suhu
$121{ }^{\circ} \mathrm{C}$ dengan tekanan $15-20$ psi selama 15 menit, kemudian didinginkan selama satu malam. Inokulasi dilakukan dengan menggunakan satu koloni jamur berukuran $4 \times 1 \mathrm{~cm}$ dari media agar-agar cawan ASK yang berumur 10 hari. Botol yang sudah diinokulasi diinkubasi pada suhu sekitar $26-28{ }^{\circ} \mathrm{C}$ sampai seluruh substratnya ditumbuhi miselium (12-14 hari).

\section{Media perlakuan}

Media perlakuan berupa TKKS yang terlebih dahulu dicacah hingga berbentuk serabut. TKKS kemudian direndam dalam air ledeng selama satu kali 24 jam dan ditiriskan dalam karung pada kondisi tertutup dan tergantung selama enam jam. Selanjutnya dibuat substrat pertumbuhan kedua isolat dengan berat $500 \mathrm{~g}$ yang terdiri dari $81 \%$ TKKS, 15\% dedak, 1,5\% gipsum, dan $1,5 \%$ kapur. Kadar air substrat diatur hingga $70 \%$. Substrat kemudian dimasukkan ke dalam kantong berukuran $35 \times 20 \mathrm{~cm}$, tebal $1 \mathrm{~mm}$, dan pada bagian ujung kantong diberi cincin berupa bambu dengan diameter $4,5 \mathrm{~cm}$. Kantong yang telah berisi substrat ditutup dengan kapas, kemudian ditutup kembali dengan kertas lalu disterilisasi di dalam autoklaf pada suhu $121{ }^{\circ} \mathrm{C}$, tekanan 15-20 psi selama dua jam. Substrat kemudian didinginkan selama \pm 12 jam.

Degradasi TKKS oleh jamur pelapuk kayu isolat JPA dan Trichoderma sp. S2-2

Percobaan menggunakan Rancangan Acak Lengkap (RAL) dengan satu faktor yaitu jenis isolat dan terdiri dari lima perlakuan inokulasi yaitu: kontrol tanpa isolat (K); isolat JPA (JPA); Trichoderma sp. S2-2 (T); isolat JPA dan Trichoderma sp. S2-2 bersama-sama (JPA+T); isolat JPA yang diinkubasi selama empat minggu kemudian disterilisasi dan media pertumbuhan isolat JPA diinokulasi dengan Trichoderma sp. S2-2 [(JPA)+T]. Masing-masing perlakuan dibuat 10 ulangan. Semua substrat yang telah diinokulasi selanjutnya diinkubasi selama delapan minggu pada suhu ruang $\left( \pm 28{ }^{\circ} \mathrm{C}\right)$. Pada akhir inkubasi, berat substrat dalam kantong diukur. Kandungan lignin, sellulosa, $\mathrm{C}, \mathrm{N}$, dan $\mathrm{C} / \mathrm{N}$ pada substrat ditentukan pada akhir inkubasi. Data dianalisis dengan ANOVA dengan nilai alpha 5\% dan uji lanjut dengan Tukey.

\section{Hasil dan Pembahasan}

Kultur isolat JPA dan Trichoderma sp. S2-2

Pada media ASK, kultur isolat JPA tumbuh lebih lambat dari pada Trichoderma sp. S2-2. Isolat JPA tumbuh memenuhi cawan Petri (diameter $9 \mathrm{~cm}$ ) setelah inkubasi delapan hari, sedangkan Trichoderma sp. S2-2 memenuhi cawan setelah inkubasi lima hari(Gambar 1). Sama halnya pada media agar cawan, pada media jagung isolat JPA tumbuh memenuhi media lebih lambat daripada Trichoderma sp. S2-2, yaitu isolat JPA selama 14 hari, sedangkan Trichoderma sp. S2-2 selama 10 hari. 


\section{Uji lignolitik dan selulolitik}

Hasil uji lignolitik isolat JPA dan Trichoderma sp. S2-2 menunjukkan bahwa kedua isolat tersebut memiliki aktivitas lignolitik yang ditandai dengan zona berwarna cokelat pada media. Isolat JPA membentuk zona berwarna coklat lebih luas pada media asam tanat dibandingkan dengan isolat Trichoderma sp. S2-2. Pada hari ke-10 masa inkubasi, seluruh media yang ditumbuhi oleh isolat JPA telah berwarna cokelat sedangkan zona cokelat pada media yang ditumbuhi oleh Trichoderma sp. S2-2 belum seluruhnya menunjukkan zona coklat. Hal ini menunjukkan bahwa aktivitas lignolitik isolat JPA lebih tinggi daripada Trichoderma sp. S2-2.

Hasil uji selulolitik menunjukkan bahwa isolat JPA memiliki aktivitas selulolitik lebih rendah dibandingkan dengan Trichoderma sp. S2-2 pada media CMC. Pada hari ke-5 pertumbuhan koloni isolat JPA belum tumbuh memenuhi media CMC sedangkan Trichoderma sp. S2-2 telah tumbuh memenuhi media CMC cawan. Hal ini menunjukkan bahwa Trichoderma sp. S2-2 tumbuh lebih baik pada media yang mengandung selulosa dibandingkan dengan isolat JPA.

Degradasi TKKS oleh jamur pelapuk kayu isolat JPA dan Trichoderma sp. S2-2

Pertumbuhan koloni kedua isolat pada TKKS pada masing-masing perlakuan memiliki perbedaan dalam waktu tumbuh memenuhi substrat TKKS (Tabel 1 dan Gambar 2). Selain itu, pengukuran berat kering substrat (Tabel 2, Gambar 3), hasil analisis kandungan lignin dan selulosa (Tabel 2), C, N, dan rasio $\mathrm{C} / \mathrm{N}$ (Tabel 3) juga menunjukkan hasil yang berbeda dari keempat perlakuan. Pada percobaan ini, lama kolonisasi untuk mencapai kolonisasi $100 \%$ paling cepat adalah pada perlakuan T. Perlakuan $\mathrm{JPA}+\mathrm{T}$ menunjukkan adanya interaksi kedua isolat. Pada hari ke-30, kolonisasi Trichoderma sp S2-2 lebih mendominasi substrat (75\%), pada hari ke 45 koloni- sasi kedua isolat adalah sama atau hampir sama (50\%), sedangkan pada hari ke-60 kolonisasi isolat JPA lebih mendominasi substrat (75\%). Namun demikian, pada media agar-agar cawan, koloni Trichoderma sp. S2-2 mampu menutupi koloni isolat JPA pada masa inkubasi 15 hari. Lama kolonisasi isolat JPA pada perlakuan (JPA)+T dan perlakuan JPA yaitu masing-masing 35 hari sedangkan lama kolonisasi isolat Trichoderma sp. S2-2 pada perlakuan perlakuan T dan (JPA)+T yaitu masing-masing 26 dan 22 hari. Secara visual, kolonisasi kedua isolat dapat dilihat pada Gambar 2.

Penurunan berat kering substrat paling tinggi terjadi pada perlakuan JPA+T $(20.54 \%)$ yang diikuti oleh perlakuan (JPA)+T (12.27\%), JPA (11.67\%), dan $\mathrm{T}(8.44 \%)$. Hal ini menunjukkan bahwa proses degradasi substrat pada perlakuan JPA+T lebih baik dibandingkan dengan perlakuan lainnya. Proses degradasi substrat mengakibatkan terjadinya reduksi berat karena sebagian besar dari unsur karbon berubah menjadi $\mathrm{CO}_{2}$ (Wahyono \& Sahwan, 2008).

Hasil analisis kandungan lignin dan selulosa pada akhir inkubasi (Tabel 2) menunjukkan adanya penurunan kandungan lignin dan selulosa pada substrat TKKS yang dikomposkan.

Penurunan kandungan lignin dan selulosa pada substrat TKKS membuktikan bahwa isolat yang digunakan dalam perlakuan memiliki kemampuan dalam mendegradasi lignin dan selulosa. Penurunan kandungan lignin terendah terdapat pada perlakuan JPA+T dengan kisaran 20,83-23,93. Nilai kisaran ini dapat terjadi karena pada perlakuan JPA+T terdapat dua bagian substrat yaitu bagian substrat yang kasar dan bagian substrat yang halus. Bagian substrat yang halus merupakan bagian substrat yang ditumbuhi oleh koloni isolat JPA dan Trichoderma sp. S2-2 sehingga diduga terjadi proses degradasi lignin dan selulosa pada substrat TKKS. Akibatnya, substrat tersebut lebih halus. Bagian substrat yang kasar merupakan bagian substrat yang ditumbuhi oleh

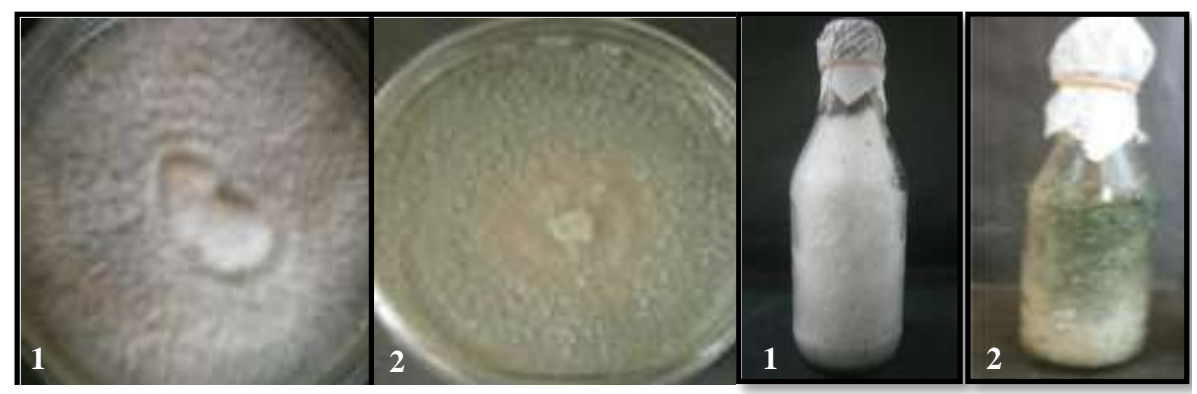

(a)

(b)

Gambar 1. Pertumbuhan koloni isolat JPA dan Trichoderma sp. S2-2 pada media ASK dan pada media jagung (a) : 1. Koloni isolat JPA dan 2. Trichoderma sp. S2-2 pada media ASK. (b) : 1. Bibit isolat JPA dan 2. Trichoderma sp. S2-2 (2) pada media jagung.

Figure 1. Colony growth of JPA isolate and Trichoderma sp.S2-2 on ASK media and corn media. (a): 1. JPA isolate and 2. Trichoderma sp. S2-2 colonies on ASK media. (b):1. JPA isolate and 2. Trichoderma sp. S2-2 colonies on corn media. 
Tabel 1. Lama kolonisasi isolat JPA dan Trichoderma sp. S2-2 pada $500 \mathrm{~g}$ substrat ( $81 \%$ TKKS, $15 \%$ dedak, $1.5 \%$ kapur, dan $1.5 \%$ gipsum).

Table 1. Colonization Lenght of JPA isolate and Trichoderma sp. S2-2 in $500 \mathrm{~g}$ of substrate ( $81 \%$ TKKS, $15 \%$ bran, $1.5 \%$ lime, dan $1.5 \%$ giypsum).

\begin{tabular}{cl}
\hline Perlakuan (Treatment) & $\begin{array}{l}\text { Kolonisasi dan lama kolonisasi (hari) } \\
\text { Colonization and lenght colonization (day) }\end{array}$ \\
\hline Kontrol & - \\
JPA & $100 \%(35$ hari/day $)$ \\
$\mathrm{T}$ & $100 \%(26$ hari/day $)$ \\
& $25 \% \mathrm{JPA}+75 \%$ Trichoderma sp.S2-2 (30 hari/day) \\
JPA+T* & $50 \%$ JPA+50\% Trichoderma sp.S2-2 (45 hari/day) \\
& $75 \%$ JPA+25\% Trichoderma sp.S2-2 (60 hari/day) \\
(JPA)+T** & $100 \%$ JPA (35 hari/day) \\
& $100 \%$ Trichoderma sp. S2-2 (22 hari/day)
\end{tabular}

Keterangan/Notes: *) Isolat JPA dan Trichoderma sp. S2-2 diinokulasi pada waktu yang sama. JPA isolate and Trichoderma sp. S2-2 inoculated simultaneously.

**) Isolat JPA yang diinkubasi selama empat minggu, kemudian substrat disterilisasi dan diinokulasi dengan Trichoderma sp. S2-2.

JPA isolate were incubated for four weeks, then the substrates were sterilized and inoculated with Trichoderma sp. S2-2.

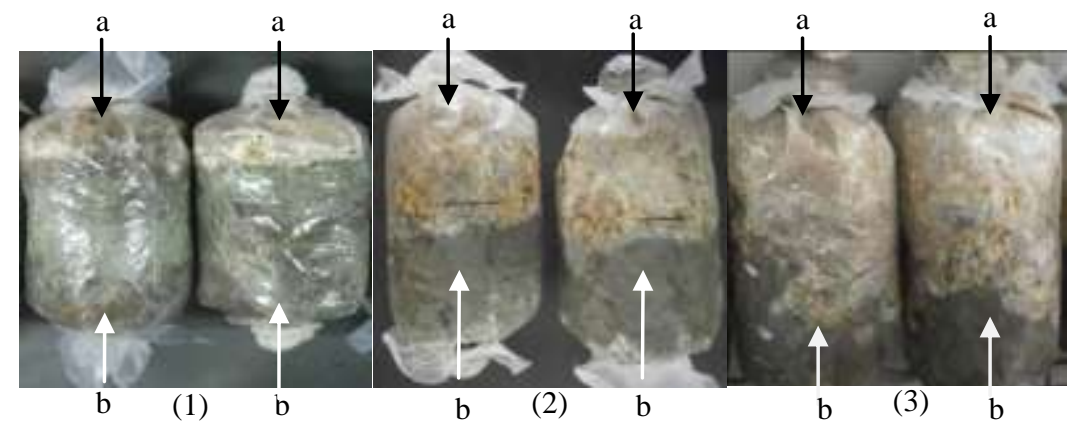

Keterangan/Notes: (1) inkubasi (incubation) 30 hari/day; (2) inkubasi (incubation) 45 hari/day; (3) inkubasi (incubation) 60 hari/day.

Gambar 2. Kolonisasi isolat JPA (a) dan Trichoderma sp. S2-2 (b) pada perlakuan JPA+T.

Figure 2. Colonization of JPA isolate (a) and Trichoderma sp. S2-2 (b) on JPA+T treatment.

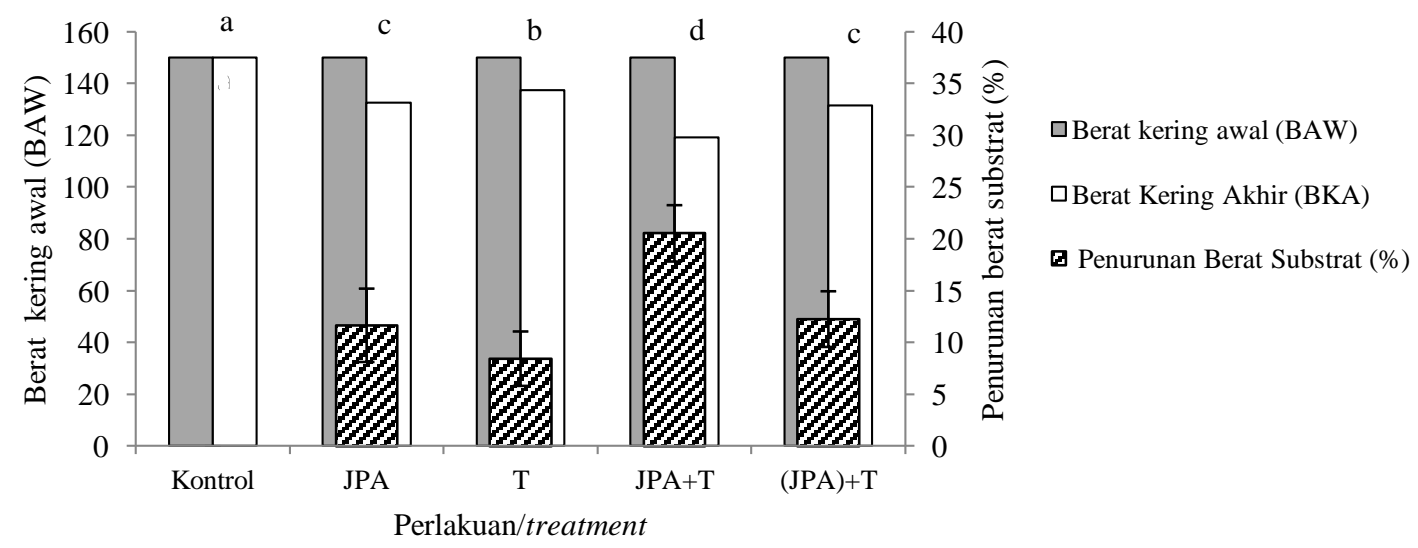

Gambar 3. Penurunan berat substrat TKKS setelah diinokulasi dengan isolat JPA dan Trichoderma sp. S2-2 selama delapan minggu. Huruf yang sama pada grafik batang yang sama menunjukkan tidak berbeda nyata berdasarkan uji Tukey dengan nilai alpha $5 \%$. Nilai adalah rata-rata dari empat perlakuan \pm standar deviasi (bar vertical).

Figure 3. TKKS substrate weight reduction after inoculation with JPA isolate and Trichoderma sp. S2-2 for eight weeks. The same letter in the same graph bar showed no significant difference by Tukey test with an alpha value of 5\%. Values were the average of the four treatments \pm deviation standard (vertical bar). 
koloni Tricho-derma sp. S2-2 tetapi tidak ditumbuhi oleh isolat JPA, sehingga proses degradasi lignin diduga tidak sebaik pada bagian substrat yang ditumbuhi oleh isolat JPA. Kandungan selulosa tertinggi terdapat pada perlakuan (JPA)+T dan JPA sedangkan kandungan selulosa terendah pada perlakuan T. Hal ini mungkin disebab-kan oleh degradasi selulosa oleh Trichoderma sp. S2-2 pada perlakuan (JPA) $+\mathrm{T}$ hanya berlangsung selama empat minggu sedangkan pada perlakuan $\mathrm{T}$ degradasi selulosa berlangsung selama delapan minggu.

Tingginya kandungan selulosa pada per-lakuan tersebut diduga karena degradasi selulosa pada perlakuan (JPA)+T dan JPA tidak selama degradasi selulosa pada perlakuan T. Diketahui bahwa Trichoderma memiliki kemampuan selulolitik yang baik, didukung oleh hasil percobaan Argo dan Yulianingsih (2010). Hal ini didukung pula oleh kemampuan tumbuh Trichoderma sp. S2-2 pada media CMC yang dilakukan dalam penelitian ini. Penurunan kandungan lignin pada semua perlakuan dalam percobaan ini masih lebih rendah jika dibandingkan dengan percobaan yang dilakukan oleh Istikowati \& Marsoem (2009) yang menggunakan isolat Phanerochaete chrysosporium untuk mendegradasi kayu randu (Ceiba pentandra Gaertn) dengan persentase penurunan kandungan lignin sebesar $3.5 \%$ atau dengan tingkat degradasi lignin setelah 40 hari inkubasi sebesar $12.28 \%$, sedangkan percobaan yang dilakukan oleh Samsuri et al. (2007) dengan menggunakan Lentinus edodes untuk mendegradasi lignin pada bagas, persentase penurunan kandungan lignin setelah empat minggu inkubasi adalah sebesar 2,4\% atau dengan tingkat degradasi lignin sebesar 9,91\%. Penurunan kandungan lignin memungkinkan perolehan selulosa, sehingga semakin banyak lignin yang terdegradasi, maka semakin besar pula peluang untuk memperoleh selulosa.

Dari hasil analisis diketahui bahwa kandungan C mengalami penurunan pada semua perlakuan (Tabel 3) sesuai yang dilaporkan Goyal et al. (2005) bahwa selama pengomposan bahan organik terjadi perubahan total kandungan C-organik dan hilangnya karbon sebagai karbon dioksida dan merupakan indikator terjadinya dekomposisi. Selain itu, rasio $\mathrm{C} / \mathrm{N}$ pada akhir degradasi juga mengalami penurunan. Rasio $\mathrm{C} / \mathrm{N}$ terendah terdapat pada perlakuan JPA+T bagian halus dengan nilai 28,24. Namun demikian, nilai rasio

Tabel 2. Kandungan lignin dan selulosa TKKS yang telah didegradasi selama delapan minggu

Table 2. The Lignin and cellulose contents of TKKS after degradation for eight weeks

\begin{tabular}{lcc}
\hline \multicolumn{1}{c}{ Perlakuan } & Lignin (Lignin) & Selulosa (Cellulose) \\
Treatments & $(\%)$ & $(\%)$ \\
\hline Kontrol & 30,89 & 51,21 \\
JPA & 21,85 & 43,33 \\
T & 24,93 & 31,90 \\
JPA+T & $20,83-23,93$ & $33,77-40,4$ \\
(JPA)+T & 23,15 & 45,51 \\
\hline
\end{tabular}

Tabel 3. Kandungan $\mathrm{C}, \mathrm{N}$, dan rasio $\mathrm{C} / \mathrm{N}$ TKKS setelah degradasi selama delapan minggu.

Table 3. The C, $N$ contents, and C/N ratio of TKKS after degradation for eight weeks.

\begin{tabular}{lccc}
\hline $\begin{array}{l}\text { Perlakuan } \\
\text { Treatments }\end{array}$ & $\begin{array}{c}\text { Kandungan C } \\
\text { C content } \\
(\%)\end{array}$ & $\begin{array}{c}\text { Kandungan N } \\
\text { N content } \\
(\%)\end{array}$ & $\begin{array}{c}\text { Rasio C/N } \\
\text { C/N ratio }\end{array}$ \\
\hline $\begin{array}{l}\text { TKKS } \\
\text { (kontrol) }\end{array}$ & 46,26 & 0,94 & 49,21 \\
JPA & 30,74 & 1,01 & 30,44 \\
T & 29,20 & 0,84 & 34,76 \\
JPA+T & $32,48-33,12$ & $1,08-1,15$ & $28,24-30,46$ \\
(JPA)+T & 35,34 & 1,16 & 30,67 \\
\hline
\end{tabular}

$\mathrm{C} / \mathrm{N}$ pada perlakuan JPA dan JPA+T bagian kasar tidak berbeda jauh dengan nilai $\mathrm{C} / \mathrm{N}$ rasio pada perlakuan (JPA)+T. Rasio C/N yang lebih rendah pada perlakuan JPA+T bagian halus mungkin disebabkan oleh meningkatnya kandungan $\mathrm{N}$ dan penurunan kandungan C. Menurut Goenadi (2006) pada proses pengomposan terjadi pelepasan $\mathrm{C}$ sehingga kandungan $\mathrm{C}$ dalam substrat menurun. Selain itu disebabkan pula oleh peningkatan unsur $\mathrm{N}$ dalam substrat. Penurunan rasio $\mathrm{C} / \mathrm{N}$ pada TKKS yang terdegradasi dengan perlakuan JPA+T hampir sama dengan rasio C/N TKKS pada percobaan yang dilakukan oleh Yelianti et al. (2009) dengan perlakuan TKKS+EM4 (rasio $\mathrm{C} / \mathrm{N}=27.50$ ) dan TKKS+Trichoderma harzianum (rasio $\mathrm{C} / \mathrm{N}=27,34$ ). Pengamatan rasio $\mathrm{C} / \mathrm{N}$ ini penting dilakukan bila bahan yang telah didegradasi akan dijadikan sebagai parameter kematangan kompos (Wahyuni, 2010).

\section{Kesimpulan}

Isolat JPA dan Trichoderma sp. S2-2 mampu mendegradasi TKKS dengan hasil degradasi terbaik pada penggunaan kedua isolat tersebut secara simultan (JPA+T). Kedua isolat berperan dalam memperoleh selulosa sebagai bahan baku untuk menghasilkan produk bernilai tambah.

\section{Daftar Pustaka}

Anindyawati T (2010). Potensi selulase dalam mendegradasi lignoselulosa limbah pertanian untuk pupuk organik. Berita Selulosa 45 (2), $70-77$.

Argo BD \& R Yulianingsih (2013). Pemanfaatan enzim selulase dari Trichoderma reseei dan Aspergillus niger sebagai katalisator hidrolisis enzimatik jerami padi dengan pretreatment microwave. $J$ Bioproses Komoditas Trop 1 (1), 36-43.

Goenadi DH \& LP Santi (2006). Aplikasi bioaktivator SuperDec dalam pengomposan limbah padat organik tebu. Bul Agr 34 (3), 173 - 180.

Goyal S, SK Dhull \& KK Kapoor (2005). Chemical and biological changes during composting of different organic wastes and assesment of compost maturity. Biores Tech 96, 1584-1591. 
Gunawan S \& A Widjaja (2012). Pengembangan teknologi produksi bioetanol generasi dua melalui pemanfaatan selulosa dan hemiselulosa dalam jerami padi. Dalam: Pros InSinas 2012, p.1-6.

Isroi (2008). Pengayaan Kompos Tandan Kosong Kelapa Sawit Untuk Meningkatkan Efisiensi Pemupukan. Diunduh dari http://isroi, wordpress.com/2008/02/08/ pengayaan-kompos-kelapa-sawit untuk meningkatkan efisiensi pemupukan. [9 Juli 2013].

Istek A, H Sivrikaya, H Eroglu \& SK Gulsoy (2005). Biodegradation of Abies bornmulleriana (Mattf.) and Fagus orientalis (L.) by the white rot fungus Phanerochaete chrysosporium, Internat Biodeter \& Biodegra 55, 63-67.

Istikowati WT \& SN Marsoem (2009). Pengaruh inokulasi jamur Phanerochaete chrysosporium Burds Terhadap kandungan kimia kayu randu (Ceiba pentandra Gaertn). Sains dan Terapan Kimia 3 (2), 144 - 153.

Lindu M, T Puspitasari \& E Ismi (2008). Sintesis dan uji kemampuan membran selulosa asetat dari Nata De Coco sebagai membran ultrafiltrasi untuk menyisih-kan zat warna pada air limbah artifisial. J Ilmu Dasar 4 (4), 107-112.

Martins LF, D Kolling, M Camassola, AJP Dillon \& LP Ramos (2008). Comparison of Penicillium echinulatum and Trichoderma reesei cellulases in relation to their activityagainst various cellulosic substrates. Biores Technol 99, 1417-1424.

Muslimah S \& ND Kuswytasari (2013). Potensi basidiomycetes koleksi biologi ITS sebagai agen bio- dekolorisasi zat warna RBBR (Remazol Brilliant Blue R). Skripsi. Surabaya, Institut Teknologi Surabaya.

Pratiwi RA, R Amelia \& R Moeksin (2013). Pengaruh volume asam (proses hidrolisis) dan waktu fermentasi pada pembuatan bioetanol dari tandan kosong kelapa sawit. J Tek Kim 19 (1), 50-53.

Ratnakomala S (2010). Produksi enzim selulase dari Trichoderma dan Streptomyces Indonesia menggunakan biomasa lignosellulosa untuk produksi bioetanol. Bogor, Pusat Penelitian Bioteknologi LIPI.

Samsuri M, M Gozan, R Mardias, M Baiquni, H Hermansyah, A Wijanarko, B Prasetya \& M Nasikin (2007). Pemanfaatan sellulosa bagas untuk produksi ethanol melalui sakarifikasi dan fermentasi serentak dengan enzim xylanase. Makara Teknol 11 (1), 17-24.

Fitria (2008). Pengolahan biomassa berlignoselulosa secara enzimatis dalam pembuatan pulp: Studi Kepustakaan. $J$ Tek Pertanian 9(2), $69-74$.

Wahyono S \& FL Sahwan (2008). Dinamika perubahan temperatur dan reduksi volume limbah dalam proses pengomposan. J Tek Ling 9, 255-262.

Wahyuni N (2010). Laju dekomposisi aerob dan mutu kompos tandan tosong kelapa sawit dengan penambahan mikroorganisme selulolitik, amandemen dan limbah cair pabrik kelapa sawit. J Penel STIPA 2(1), 10-32.

Yelianti U, Kasli, M Kasim \& EF Husin (2009). Kualitas pupuk organik hasil dekomposisi beberapa bahan organik dengan dekomposernya. J Akta Agrosia 12 (1),1-7. 